\title{
Gonadotropin-stimulated epidermal growth factor receptor expression in human ovarian surface epithelial cells: involvement of cyclic AMP-dependent exchange protein activated by cAMP pathway
}

\author{
Jung-Hye Choi ${ }^{1,5 *}$, Chien-Lin Chen ${ }^{2,3 *}$, Song Ling Poon ${ }^{1}, H_{s i n-S h i h ~ W a n g}{ }^{2,4}$ \\ and Peter C K Leung ${ }^{1}$
}

\footnotetext{
${ }^{1}$ Department of Obstetrics and Gynecology, British Columbia Research Institute for Children's and Women's Health, University of British Columbia, 2H-30, 4490 Oak Street, Vancouver, British Columbia, Canada V6H 3V5

${ }^{2}$ Graduate Institute of Clinical Medical Sciences, College of Medicine, Chang Gung University, Taoyuan, Taiwan, ROC

${ }^{3}$ Center for Traditional Chinese Medicine, Chang Gung Memorial Hospital, Taoyuan, Taiwan, ROC

${ }^{4}$ Department of Obstetrics and Gynecology, Lin-Kou Medical Center, Chang Gung Memorial Hospital, Taoyuan, Taiwan, ROC

${ }^{5}$ Department of Oriental Pharmacy, College of Pharmacy, Kyung Hee University, Seoul, South Korea

(Correspondence should be addressed to P C K Leung; Email: peleung @ interchange.ubc.ca)

*J-H Choi and C-L Chen contributed equally to this work
}

\begin{abstract}
In addition to their critical roles in folliculogenesis and ovarian granulosa cell steroidogenesis, gonadotropins have been implicated as potential risk factors in ovarian epithelial carcinomas, most of which are derived from ovarian surface epithelium (OSE). However, the molecular mechanism underlying the effects of FSH and LH in OSE and its neoplastic counterpart is not well understood. We previously demonstrated that gonadotropins promote the growth of OSE cells by regulating the levels of epidermal growth factor receptor (EGFR) via the activation of ERK $1 / 2$ and PI3K pathways in immortalized human OSE (IOSE) cells. In this study, we investigated whether cAMP and its novel binding target, named exchange protein activated by cAMP (Epac), are involved in the gonadotropin-induced EGFR expression in OSE cells. Gonadotropins elevated intracellular cAMP levels in both IOSE and granulosa cells, and this increase was attenuated by SQ22536, an inhibitor of adenylyl cyclase (AC). The activation of the ERK1/2 and Akt pathways as well as the expression of EGFR was stimulated by reagents that elevate intracellular cAMP levels, via cAMP analog 8-bromo-cAMP and AC activator forskolin. A similar increase was observed when the cells were treated with a novel cAMP analog, 8-(4-chlorophenylthio)-2'-O-methyl adenosine-3', 5'-cyclic monophosphate (8-CPT-2ME-cAMP), which activates Epac specifically but not PKA. Moreover, the gonadotropin-induced EGFR expression and ERK1/2 and Akt activation were abolished by overexpression of dominant negative Epac. Taken together, these results indicate that the AC/CAMP/Epac signaling pathway may mediate the up-regulation of EGFR by gonadotropins via ERK1/2 and Akt activation.
\end{abstract}

Endocrine-Related Cancer (2009) 16 179-188

\section{Introduction}

Ovarian cancer is the sixth most common cancer and the fifth leading cause of cancer-related deaths among women in developed countries (Greenlee et al. 2000). Worldwide, the total number of cases is $\sim 190000$ per year (Gadducci et al. 2004). About 1 out of 70 women in the United States will develop ovarian cancer (Quirk \& Natarajan 2005). Approximately $90 \%$ of malignant tumors arise from the ovarian surface epithelium (OSE), a single layer of flat-to-cuboidal epithelial cells covering the ovary (Nicosia \& Johnson 1984), 
while the rest originate from granulosa cells $(\sim 5 \%)$ or, rarely, germs cells $(\sim 1 \%)$. While studies on the ovary have mainly focused on the other cell types such as granulosa and theca cells, which play a critical role in folliculogenesis and steroidogenesis, the OSE was among the least characterized compartments of the ovary. In particular, the cellular and molecular mechanisms by which it undergoes tumor formation and neoplastic progression are not understood.

The etiology of ovarian epithelial cancer (OEC) remains largely unknown. To date, family history of ovarian cancer, age, and nulliparity have been recognized as risk factors of OEC, while pregnancy, oral contraceptive use, hysterectomy, and tubal ligation are protective factors (Holschneider \& Berek 2000, Hanna \& Adams 2006). There is evidence that several key reproductive hormones including gonadotropins can influence the incidence and/or growth characteristics of ovarian cancer cells (Riman et al. 1998, Gadducci et al. 2004, Lukanova \& Kaaks 2005). The gonadotropin hypothesis proposes that excessive levels of gonadotropins, related to the surge occurring during ovulation and the loss of gonadal negative feedback associated with menopause and premature ovarian failure, may play a role in the development and progression of OEC (Biskind \& Biskind 1944, Cramer \& Welch 1983). In support of this hypothesis, both FSHR and LHR have been found to be expressed in normal OSE cells and ovarian tumors (Lu et al. 2000, Minegishi et al. 2000, Zheng et al. 2000, Parrott et al. 2001, Choi et al. 2002). Numerous studies have suggested that gonadotropin modulates gene expression leading to changes in cell growth, apoptosis, and/or metastasis of OSE as well as ovarian cancer, suggesting the potential involvement of gonadotropins in ovarian cancer development (Konishi 2006). However, the exact molecular mechanism of gonadotropins in OSE and OEC cells is not well characterized.

It has been well demonstrated that the overexpression and aberrant activation of epidermal growth factor receptor (EGFR) are related to tumor development, progression, recurrence, and poor prognosis in numerous cancers (Salomon et al. 1995a,b, Nicholson et al. 2001). In ovarian cancer, EGFR is frequently amplified and/or overexpressed, and a TGF $\alpha$ (or EGF)/EGFR autocrine loop contributes to the cell growth (Owens et al. 1991, Berns et al. 1992, Owens \& Leake 1992, Brader et al. 1998, Alper et al. 2000). Elevated expression of EGFR may, therefore, play an important role in tumorigenesis and cancer progression in ovarian epithelium. Despite these observations, the exact mechanism of the regulation of EGFR expression in
OSE and its malignant counter part is not clearly understood. In a previous study, we have demonstrated that the treatment with FSH and LH significantly increased Egfr mRNA and EGFR protein in the immortalized OSE cells (Choi et al. 2005). In addition, IOSE cells co-treated with gonadotropins and EGF revealed a significant stimulation of mitogenesis. These results suggest that an increased level of EGFR induced by gonadotropins in preneoplastic OSE cells may contribute to the uncontrolled growth, as an important driving force for the tumorigenesis. In this regard, it is crucial to understand the molecular mechanism by which gonadotropins increase the levels of EGFR.

Gonadotropin receptors are G-protein-coupled receptors (GPCRs) with seven transmembrane domains. It is generally accepted that the protein kinase A (PKA) pathway mediates the effects of gonadotropins on granulosa cells, such that activation of adenylate cyclase by the stimulatory G-protein, $\mathrm{G} \alpha$ s, is followed by a rapid increase in cAMP and a subsequent activation of PKA (Hsueh et al. 1984). Interestingly, growing evidence suggests that FSHR and LHR can activate a number of additional signaling pathways such as protein kinase C (PKC), PI3K, and MAPK in both a cAMP/PKA-dependent and -independent manner in granulosa cells (Pennybacker \& Herman 1991, Flores et al. 1992, Cameron et al. 1996, Das et al. 1996, Herrlich et al. 1996, Chiang et al. 1997, Babu et al. 2000, Gonzalez-Robayna et al. 2000, Sekar \& Veldhuis 2001, Cunningham et al. 2003, Alam et al. 2004). Moreover, a new binding target of the cAMP named exchange protein directly activated by cAMP (Epac) has been recently identified (Kawasaki et al. 1998, de Rooij et al. 1998), which may also be implicated in gonadotropin actions. Previously, we have demonstrated that gonadotropins up-regulate EGFR expression through the activation of the ERK1/2 and PI3K pathways, but not PKA, in IOSE cells (Choi et al. 2005). In the present study, we investigated whether cAMP and/or Epac is involved in the gonadotropin-induced EGFR in IOSE cells.

\section{Materials and methods}

\section{Material}

Human LH and recombinant FSH were provided by Dr A F Parlow (National Hormone and Pituitary Program, Harbor-University of California Los Angels Medical Center, Torrance, CA, USA). 8-Br-cAMP (8-bromoadenosine 4, 5-cyclic monophosphate), 8-CPT-2ME-cAMP (8-(4-chloro-phenylthio)-2'-O-methyladenosine- $3^{\prime}, 5^{\prime}$-cyclic monophosphate), SQ22536 
(9-(tetrahydro-2-furanyl)-9H-purin-6-amine), EGTA (ethylene-bis (oxyethyl enenitrilo) tetraacetic acid), BAPTA-AM (1,2-bis(2-aminophenoxy) ethane$N, N, N^{\prime}, N^{\prime}$-tetraacetic acid tetrakis (acetoxymethyl ester)), and forskolin were purchased from Sigma. Antibody against EGFR and $\beta$-actin were purchased from Santa Cruz Biotechnology (Santa Cruz, CA, USA). Phospho ERK1/2 and Akt were obtained from Cell Signaling Technology (Beverly, MA, USA). Antibody against Epac was purchased from Gene Tex Incorporation (San Antonio, TX, USA).

\section{Cell culture}

Following follicular aspirates that were collected during oocyte retrieval from women undergoing $I V F$, SVOG-4M human granulosa luteal cells (hGLC) were prepared as previously described (Peng et al. 1994). Non-tumorigenic SV40 tag-immortalized OSE-derived cells (IOSE-80, IOSE-80PC, and IOSE-120) were cultured as previously described (Choi et al. 2001) in medium 199:MCDB 105 (1:1; Sigma-Aldrich Corp.) containing $10 \%$ fetal bovine serum (Hyclone Laboratories Ltd, Logan, UT, USA), $100 \mathrm{U} / \mathrm{ml}$ penicillin G, and $100 \mu \mathrm{g} / \mathrm{ml}$ streptomycin (Life Technologies Inc.) in a humidified atmosphere of $5 \% \mathrm{CO}_{2}-95 \%$ air at $37^{\circ} \mathrm{C}$. At confluency, the cells were passaged with $0.06 \%$ trypsin (1:250)/0.01\% EDTA in $\mathrm{Mg}^{2+} / \mathrm{Ca}^{2+}$ - free Hank's buffered salt solution (HBSS).

\section{ELISA for intracellular cAMP}

To measure intracellular cAMP levels, IOSE and SVOG-4M cells $\left(1 \times 10^{4}\right.$ cells/well $)$ were plated onto 96-well microplates and cultured for $24 \mathrm{~h}$. The cells were then pre-incubated in serum-free medium for $30 \mathrm{~min}$ and treated with FSH or $\mathrm{LH}$ for 0,5 , or $15 \mathrm{~min}$. Intracellular cAMP levels were measured using a cAMP Biotrak enzyme immunoassay system (Amersham Pharmacia Biotech), according to the manufacturer's suggested procedure.

\section{Cell transfection}

Dominant negative Epac (DN-Epac) mutant EpacR279E was generously provided by Dr X Cheng (Department of Pharmacology and Toxicology, University of Texas Medical Branch). DN-Epac vector or empty vector was transfected into IOSE cells using FuGENE 6 (Roche Applied Science) according to the manufacturer's suggested protocol at $50 \%$ confluence on six-well plates. The transfected cells were grown for $24 \mathrm{~h}$ and used for further experiments (Fig. 6).

\section{Immunoblot analysis}

The cells were seeded at a density of $2 \times 10^{5}$ cells in $35 \mathrm{~mm}$ culture dishes and cultured. The cells were washed once with medium, and serum starved for at least $2 \mathrm{~h}$ prior to treatments with sample. The cells were washed twice with ice-cold PBS and lysed in ice-cold radioimmuno precipitation assay (RIPA) buffer (150 mM NaCl, $1 \%$ Nonidet P-40, 0.5\% deoxycholate, $0.1 \%$ SDS, $50 \mathrm{mM}$ Tris (pH, 7.5), $1 \mathrm{mM}$ phenylmethylsulphonyl fluoride, $10 \mu \mathrm{g} / \mathrm{ml}$ leupeptin, and $100 \mu \mathrm{g} / \mathrm{ml}$ aprotinin). The extracts were placed on ice for $15 \mathrm{~min}$ and centrifuged to remove cellular debris. The protein concentration of supernatants was determined using the Bradford assay (Bio-Rad Laboratories). Thirty microgram of total protein was run on $10 \%$ SDS-polyacrylamide gels and electrotransferred to a nitrocellulose membrane (Amersham Pharmacia Biotech). The membrane was immunoblotted using specific primary antibodies at $4{ }^{\circ} \mathrm{C}$ overnight. After washing, the signals were detected with HRP-conjugated secondary antibody for $1 \mathrm{~h}$, and visualized using the ECL chemiluminescent system (Amersham Pharmacia Biotech).

\section{Rap1 activation assay}

Rap1 activity was detected by a Rap1 activation assay kit (Upstate Biotechnology Inc., Lake Placid, NY, USA) following the manufacturer's instructions. Briefly, cells were lysed with $1 \mathrm{ml}$ lysis buffer and Rap1-GTP were pulled down using the glutathione $S$-transferase fusion protein corresponding to human RBD of RalGDS bound to agarose. The agarose beads were washed with ice-cold lysis buffer thrice, and bound proteins were eluted in $40 \mu \mathrm{l} 2 \mathrm{X}$ SDS sample buffer. Immunoblot (see above) was performed with anti-Rap1 (Upstate Biotechnology) antibody.

\section{Results}

\section{Effect of FSH and LH on intracellular cAMP levels}

Considering that gonadotropins have shown to stimulate a cAMP-independent pathway in several cell systems, we investigated whether the OSE cells can respond to gonadotropin stimulation by increasing cAMP levels as do granulosa cells. Three immortalized ovarian surface epithelial cells (IOSE-80, IOSE-120, and IOSE-80PC) and one immortalized hGLC (SVOG$4 \mathrm{M}$ ) were treated with FSH or LH, and then cAMP levels were measured using ELISA. As shown in Fig. 1, FSH and LH induced a four- to sixfold increase of intracellular cAMP levels in SVOG-4M cells which was used as a positive control. All three IOSE cells had 


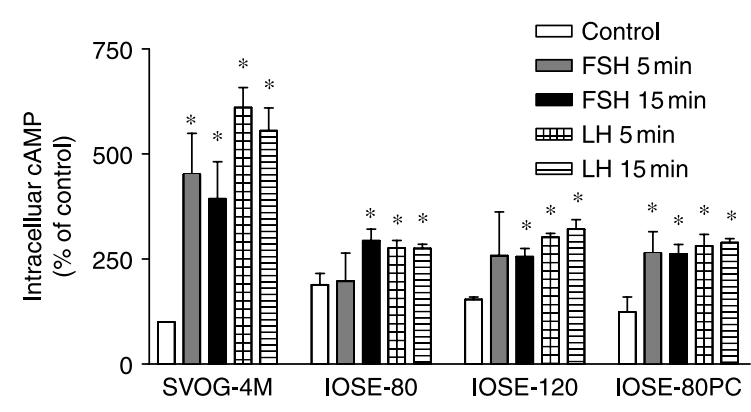

Figure 1 Effect of FSH and LH on intracellular cAMP levels in IOSE cells. The cells were treated with $\mathrm{FSH}(100 \mathrm{ng} / \mathrm{ml})$ or $\mathrm{LH}$ $(100 \mathrm{ng} / \mathrm{ml})$ for 0,5 , and $15 \mathrm{~min}$. As described in the Materials and Methods, ELISA was performed to evaluate the intracellular cAMP levels. SVOG-4M, human granulosa luteal cells were used as a positive control. Data are shown as the means of three individual experiments performed in triplicate and are presented as the mean \pm S.D. ${ }^{\star} P<0.05$ vs 0 min, Student's $t$ test.

comparable or slightly increased basal levels of cAMP when compared with SVOG-4M cells. Treatment with FSH or LH for 15 min substantially stimulated the cAMP levels in IOSE cells, although the stimulatory effect was less potent than that in SVOG-4M cells.

\section{Involvement of increased cAMP in gonadotropin- induced EGFR up-regulation}

We have previously shown that gonadotropins up-regulate the EGFR through the activation of the ERK $1 / 2$ and PI3K pathways in IOSE-80 and IOSE80PC cells (Choi et al. 2005). IOSE-80PC, a post-crisis cell line originally generated from IOSE-80, showed similar EGFR mRNA and protein expressions as IOSE-80 cells. Subsequently, further experiments were performed using IOSE-80PC to evaluate the mechanism of gonadotropins on the expression of EGFR. To evaluate whether the gonadotropin-induced cAMP levels was involved in the modulation of gonadotropin-induced EGFR expression in IOSE80PC cells, cAMP analog 8-Br-cAMP $(0.5 \mathrm{mM})$ and an adenylate cyclase activator forskolin $(10 \mu \mathrm{M})$ were used to investigate the activation of ERK1/2, Akt and the expression level of EGFR. Figure 2 demonstrated that 8-Br-cAMP or forskolin enhanced the phosphorylation of ERK1/2 and Akt (Fig. 2, data shown for three independent paired experiments, lanes 1 vs 4,2 vs 5 , and 3 vs 6). In addition, treatment with forskolin or 8-Br-AMP for $24 \mathrm{~h}$ increased EGFR protein level in the IOSE cells (Fig. 3).

Several studies have suggested that gonadotropins play a role in proliferation and steroidogenesis through a cAMP-dependent or -independent increase in intracellular calcium ion levels in a number of cell

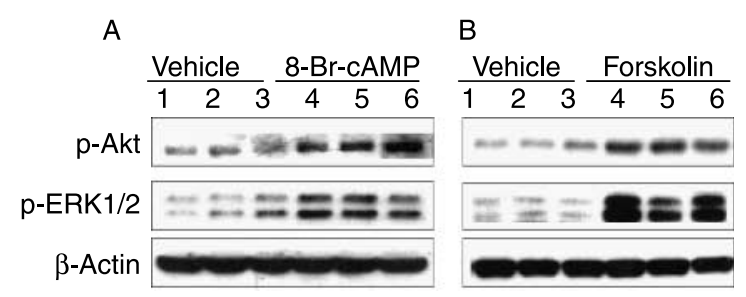

Figure 2 Effect of (A) 8-Br-cAMP and (B) forskolin on the activation of the ERK $1 / 2$ and Akt in IOSE cells. The phosphorylation of ERK $1 / 2$ and Akt was examined in IOSE80PC cells after treatment with 8-Br-cAMP $(0.5 \mathrm{mM})(\mathrm{A})$ or forskolin $(10 \mu \mathrm{M})(B)$ for $15 \mathrm{~min}$, and immunoblot analysis was performed as described in the Materials and Methods. The phosphorylated ERK1/2 and AKT (Ser473) were normalized by $\beta$-actin. Three independent paired experiments, lanes 1 vs 4,2 vs 5 , and 3 vs 6 .

systems. Using extracellular and intracellular calcium chelators, EGTA and BAPTA-AM respectively, we evaluated the possible involvement of intracellular calcium ion in the gonadotropin-increased EGFR expression in IOSE-80 and IOSE80-PC cells. Neither of calcium ion chelators significantly inhibited the changes in EGFR expression induced by gonadotropins. By contrast, pretreatment with an adenylate cyclase inhibitor SQ22536 markedly blocked the stimulatory effect of gonadotropins on EGFR expression (Fig. 4).

\section{Effect of Epac-specific cAMP analog on the activation of ERK1/2 and Akt and expression of EGFR}

In the previous study, we failed to demonstrate the involvement of PKA pathway in the gonadotropininduced EGFR up-regulation in IOSE cells (Choi et al. 2005). In this regard, it seems reasonable to examine a new target of cAMP, Epac, also known as 'cAMP guanine nucleotide exchange factors' (cAMP-GEFs; Kawasaki et al. 1998, de Rooij et al. 1998). First, using immunoblot analysis, we demonstrated the basal expression of Epac in all three IOSE cells (Fig. 5A). To investigate whether gonadotropins- or cAMP-induced

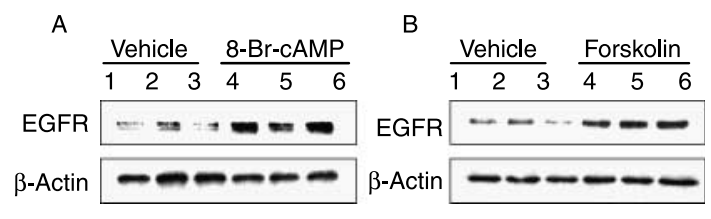

Figure 3 Effect of (A) 8-Br-cAMP and (B) forskolin on EGFR expression in IOSE cells. The expression of EGFR was examined following treatment with 8-Br-cAMP $(0.5 \mathrm{mM})$ or forskolin $(10 \mu \mathrm{M})$ for $24 \mathrm{~h}$, and immunoblot analysis was performed as described in the Materials and Methods. Three independent paired experiments, lanes 1 vs 4,2 vs 5 , and 3 vs 6 . 


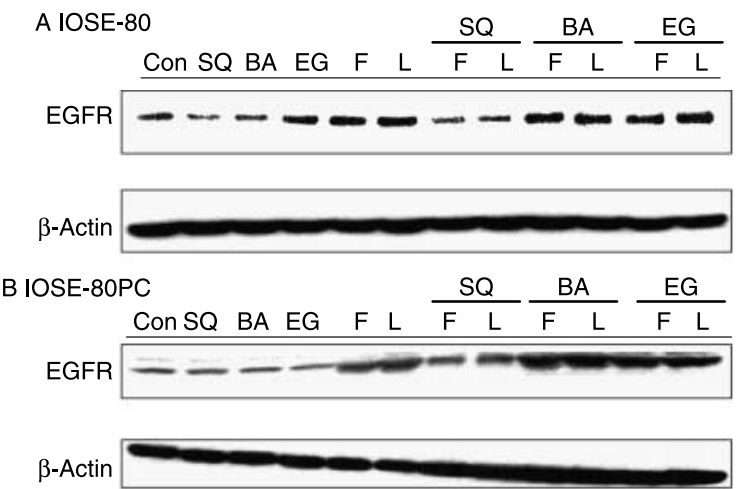

Figure 4 Effect of SQ22536, BAPTA-AM, and EGTA on gonadotropin-induced EGFR up-regulation in IOSE cells. SQ22536 $(50 \mu \mathrm{M})$, BAPTA-AM $(50 \mu \mathrm{M})$, or EGTA $(1 \mathrm{mM})$ were pretreated for $20 \mathrm{~min}$ in (A) IOSE-80 and (B) IOSE-80PCfollowed by the administration of $\mathrm{FSH}(100 \mathrm{ng} / \mathrm{ml})$ or $\mathrm{LH}$ (100 ng/ml) for $24 \mathrm{~h}$, and the expression of EGFR was examined by Immunoblot analysis. SQ, SQ22536; BA, BAPTA-AM; EG, EGTA; F, FSH (100 ng/ml); L, LH (100 ng/ml). Each blot is representative of three independent experiments.

EGFR up-regulation is associated with Epac, the IOSE cells were treated with a new cAMP analog, 8-(4-chloro-phenylthio)-2'- $O$-methyladenosine- $3^{\prime}, 5^{\prime}$ cyclic monophosphate (8-CPT-2ME-cAMP), which specifically activates Epac, but not PKA. As shown in Fig. 5B, treatment with 8-CPT-2ME-cAMP analog induced an increase in phosphorylated ERK1/2 and Akt within $5 \mathrm{~min}$ in IOSE cells. The level of phosphorylated Akt reached the maximum at $15 \mathrm{~min}$, followed by a decline evident at $30 \mathrm{~min}$. The activated ERK1/2 declined to the control at $30 \mathrm{~min}$ while the activated Akt was still competitive compared with 0 min. Similarly, the Epac-specific cAMP analog increased EGFR expression in a time-dependent manner (Fig. 5C).

\section{Effect of Epac on the gonadotropin-induced EGFR up-regulation}

Transient transfection with dominant negative Epac (DN-Epac) vector was performed to evaluate whether Epac is involved in response to gonadotropins in IOSE cells. Rap-1 activation assay showed that treatment with FSH or LH for 15 and 30 min activates Rap1, a downstream target of Epac in empty vector-transfected cells while the gonadotropin effect was abolished in DN-Epac-expressing IOSE cells. In addition, the Epacmutant inhibited the gonadotropin-induced ERK1/2 and Akt activation (Fig. 6A). These observations showed that the cAMP-Epac-Rap1 pathway mediates gonadotropins effect and the expression of Epac mutant biologically inhibits Epac activity in IOSE cells. Furthermore, EGFR was significantly enhanced
A
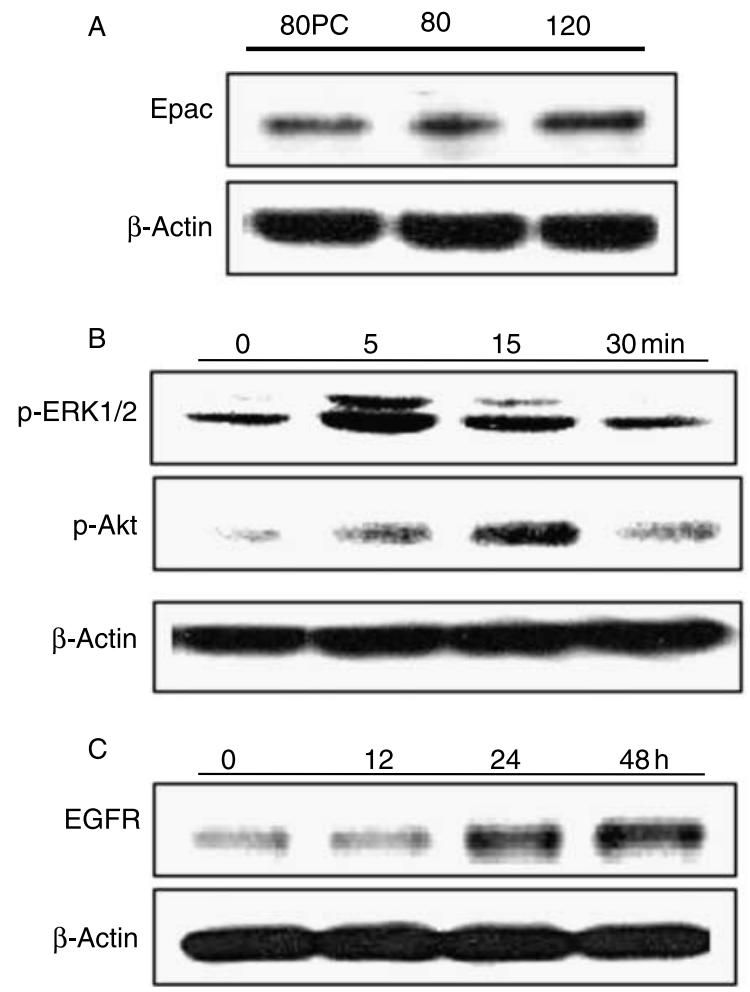

Figure 5 Effect of 8-CPT-2ME-cAMP on the activation of ERK1/2 and Akt and expression of EGFR. (A) The levels of Epac protein in IOSE cells (IOSE-80PC, IOSE-80, and IOSE-120) were demonstrated using immunoblot analysis. (B) Following treatment with 8-CPT-2ME-cAMP $(10 \mu \mathrm{M})$ in a time-dependent manner $(0,5,15$, and $30 \mathrm{~min})$, the phosphorylation of ERK $1 / 2$ and Akt was evaluated. (C) The expression level of EGFR was examined in IOSE cells following treatment with 8-CPT-2ME-cAMP $(10 \mu \mathrm{M})$ in a time-dependent manner $(0,12,24$, and $48 \mathrm{~h})$. Each blot is representative of at least three independent experiments.

in empty vector-transfected IOSE cells but not in DN-Epac-transfected IOSE cells after treatment with FSH or LH $(100 \mathrm{ng} / \mathrm{ml})$ for $24 \mathrm{~h}$ (Fig. 6B). These results suggest that Epac mediates the gonadotropininduced EGFR expression in IOSE cells.

\section{Discussion}

Until recently, the cAMP/PKA is generally recognized as the major signaling pathway mediating gonadotropin actions in the ovary. However, increasing evidence over the past few years has implicated the involvement of additional second messengers such as PKC, PI3K, and MAPK in FSHR and LHR signaling in granulosa cells (Pennybacker \& Herman 1991, Flores et al. 1992, Cameron et al. 1996, Das et al. 1996, Herrlich et al. 1996, Chiang et al. 1997, Babu et al. 2000, Gonzalez-Robayna et al. 2000, Sekar \& Veldhuis 2001, Cunningham et al. 2003, Alam et al. 2004). 


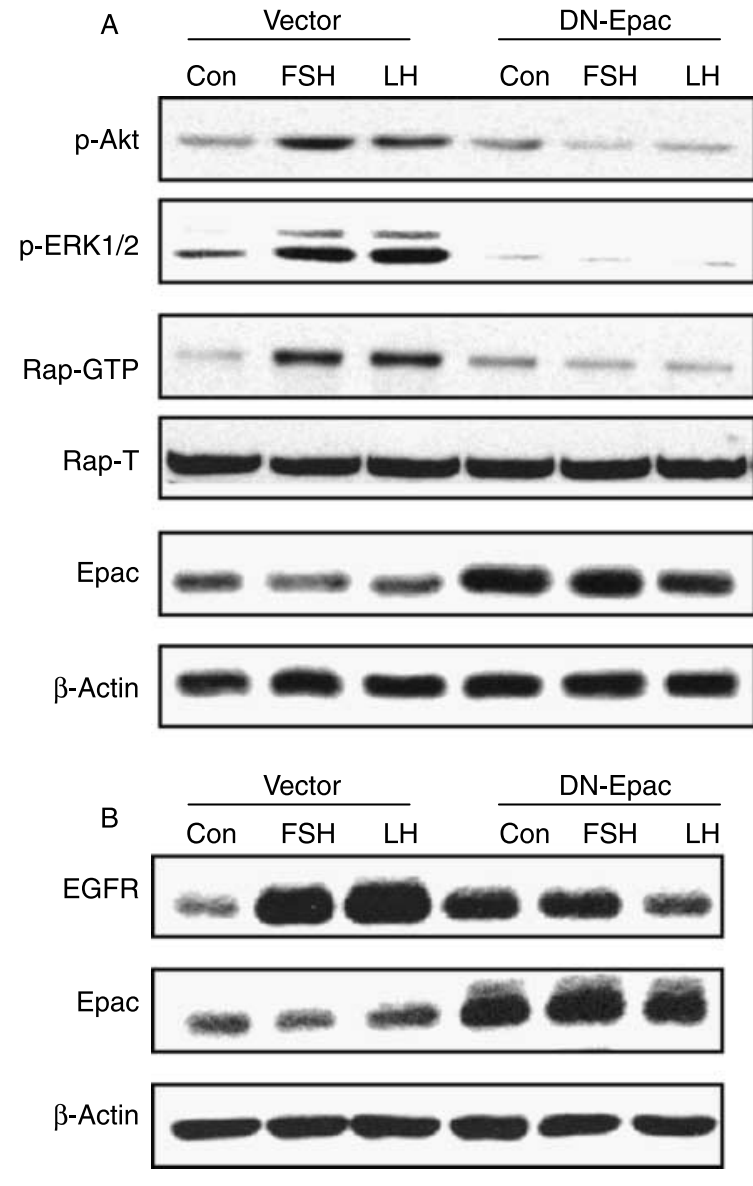

Figure 6 Effect of dominant negative Epac on (A) gonadotropininduced ERK1/2 and Akt activation and (B) EGFR up-regulation. Following transient transfection of cells with DN-Epac or empty vector control for $24 \mathrm{~h}$, the cells were treated with $100 \mathrm{ng} / \mathrm{ml} \mathrm{FSH}$ or LH for $15 \mathrm{~min}$. The activation of ERK $1 / 2$ and Akt was evaluated by immunoblot analysis using phosphoERK1/2 and Akt antibody. The activity of Rap1 was determined using RalGDS-Rap1-binding domain (RBD) as an activationspecific probe and subsequently quantified by Immunoblot analysis (Rap1-GTP). To ensure that equal amounts of protein were analyzed, Rap1 levels were determined in whole cell lysates. (A) Vector control or DN-Epac-transfected IOSE cells were treated with $100 \mathrm{ng} / \mathrm{ml} \mathrm{FSH}$ or LH for $24 \mathrm{~h}$, and $(\mathrm{B})$ the expression of EGFR was evaluated by immunoblot analysis using EGFR antibody.

In addition to their essential role within the ovarian follicles, gonadotropins also exert direct effects in OSE and OEC cells. However, the exact mechanism underlying the actions of gonadotropins in OSE and OEC cells is not understood.

Recently, we have demonstrated that treatment of IOSE cells with gonadotropins increased the expression of EGFR, resulting in an enhanced stimulation of mitogenesis in presence of EGF (Choi et al. 2005). Moreover, the stimulatory effect was mediated by the activation of the PI3K and ERK1/2 pathways, but not by PKA pathway which is a classical binding target of gonadotropin-induced cAMP. This finding suggests the involvement of another second messenger such as intracellular calcium ion and/or an alternative binding target of cAMP in the gonadotropin signaling in OSE cells. In this study, we found that gonadotropin-induced EGFR expression is not dependent on the stimulation of calcium influx, but mediated by the activation of adenylate cyclase followed by an increase in cAMP levels. We also demonstrated, for the first time, that the novel target of cAMP, Epac, is expressed in IOSE and ovarian cancer cells, and Epac may well mediate the gonadotropin-induced activation of the ERK1/2 and Akt, resulting in EGFR up-regulation in IOSE-cells. The effect of gonadotropins on EGFR expression appears to be more potent in normal or early stages of cancers which may have low basal EGFR levels (Choi et al. 2005). In addition, IOSE-80 cells treated with gonadotropins and EGF exhibited an additive stimulation of mitogenesis. These findings indicate that gonadotropins can stimulate EGFR expression in OSE during menopause, and this effect is associated with the initiation of the ovarian cancer because postmenopausal women have high gonadotropin levels in their serum. Thus, the understanding of the regulatory mechanism of EGFR expression in OSE may provide important insights into the mechanism that controls a response of OSE to EGF and/or TGF $\alpha$ through the modulation of its receptor levels.

Numerous reports have demonstrated that binding of gonadotropins to their receptors can increase inositol phosphate and accumulate intracellular calcium in granulosa cells (Veldhuis 1987, Flores et al. 1990, Gilchrist et al. 1996, Hirsch et al. 1996). Coupling of activated LHR to the Gi subunit stimulated PLC to synthesize inositol-1,4,5-triphospate (IP3) and diacylglycerol, resulting in the elevation of intracellular calcium ion levels and activation of PKC (Herrlich et al. 1996, Flores et al. 1998, Kuhn \& Gudermann 1999). These findings are consistent with previous observations that not only Gs but also other G proteins including $\mathrm{Gi}$ and $\mathrm{Gq} / 11$ interact with gonadotropin receptors with stimulating additional secondary messengers; thus, both cAMP and IP3 are activated (Hirsch et al. 1996, Wang et al. 1997, Cooke 1999, Kuhn \& Gudermann 1999). In addition, it is of interest that FSHR-3, which is an alternate splicing variant of FSHR containing growth type-1 receptor motif, leads to a cAMP-independent but calcium-dependent ERK1/2 activation (Babu et al. 2000, Touyz et al. 2000). In the present study, we have demonstrated that cAMP, but not calcium, is associated with gonadotropininduced EGFR up-regulation. However, whether 
calcium-dependent pathway can mediate other response to the gonadotropins in IOSE cells remains to be elucidated.

Recently, the MAPK and PI3K have been recognized as two major downstream kinases of cAMP. For example, studies performed in the rat (Das et al. 1996, Gonzalez-Robayna et al. 2000) and pig (Cameron et al. 1996) granulose cells and human luteinized granulosa cells (Dewi et al. 2002) have demonstrated that FSH and LH stimulate the activation of ERK1/2 and/or p38, the two members of the MAPK family, in a cAMP/ PKA-dependent manner. Moreover, with the identification of a new class of cAMP-binding proteins, there is a growing body of evidence for cAMP-dependent but PKA-independent kinase activation (Kawasaki et al. 1998, de Rooij et al. 1998). This protein, named exchange proteins directly activated by cAMP (Epacs) and also known as 'cAMP guanine nucleotide exchange factors' (cAMP-GEFs), is activated by cAMP. Gonzalez-Robayna et al. found that FSH and cAMP analogs activate Akt and PI3K inhibitor LY294002, but not PKA inhibitor H89 inhibits this activation. By contrast, the expression and activation of Sgk, which is a serum- and glucocorticoid-inducible kinase and associated with proliferative stages of granulosa cell, were regulated by the PI3K and p38 MAPK. Thus, it was speculated that Epac might be responsible for the cAMP-mediated phosphorylation of Akt and Sgk via PI3K, while PKA is obligatory for the transcription of Sgk in granulosa cells. Furthermore, the Epac might be related to LH-stimulated progesterone production in hGLC. In hGLC, treatment with 8-CPT-2 ME-cAMP, the cAMP-GEF-specific cAMP analog that does not react with PKA, increased progesterone synthesis and secretion in a dosedependent manner (Chin \& Abayasekara 2004). These observations are in accordance with our finding that involvement of Epac in the gonadotropin- and cAMP-induced ERK1/2 and Akt activation in IOSE cells. However, the mechanism by which Epac regulates ERK1/2 and Akt in IOSE cells remains unclear. It is accepted that Epac controls small GTPases, such as Rap1 (Kawasaki et al. 1998, de Rooij et al. 1998). The GTPase stimulates Raf and/or Ras kinase and leads to the activation of the PI3K/Akt and MAPK pathways, suggesting that gonadotropininduced activation of ERK1/2 and Akt might be mediated by the cAMP/Epac/Rap1/Ras (or Raf) pathway (Gonzalez-Robayna et al. 2000, Gao et al. 2006). In addition, a study suggested that an interaction between $\mathrm{T}$ cell leukemia 1 and Epac1 regulates the activation and distribution of Akt (Misra et al. 2008).
Interestingly, inhibition of Epac activation by DN-Epac, by itself, did not show any mitogenic change in IOSE cells while the treatment of DN-Epac transfected IOSE cells with gonadotropins induced a decrease in cell proliferation. This result suggests that stimulation by gonadotropins is required for Epacmediated cell proliferation as well as EGFR expression.

It is noteworthy that 8-CPT-2ME-cAMP induced phosphorylation of ERK1/2 and Akt within 5 min with the decrease of their level at $15 \mathrm{~min}$ and $30 \mathrm{~min}$ respectively (Fig. 5B). Similarly, we had demonstrated that treatment with gonadotropins induced a significant increase in the phosphorylated form of ERK1/2 and Akt at $5 \mathrm{~min}$, and the activated ERK1/2 and Akt began to decline at 15-60 min in IOSE cells. These results indicate that 8-CPT-2ME-cAMP can mimic the pattern of gonadotropin-induced signaling in IOSE cells and the activation of ERK1/2 and Akt at 5-30 min may play a critical role in gonadotropin-regulated EGFR expression.

In ovarian cancer cells, cAMP has been shown to mediate integrin-dependent adhesion of OVCAR-3 cells to fibronectin through the Epac (Rangarajan et al. 2003). It is of note that our immunoblot analysis revealed that Epac protein is highly expressed in IOSE cells, while it is hardly detectable in ovarian cancer cells including OVCAR-3 cells (Data not shown). Further experiments will be warranted to evaluate whether the significant change in Epac expression from premalignant IOSE cells to its neoplastic counterpart is associated with differential responses to gonadotropins stimulation in OSE and ovarian cancer cells. Moreover, we have previously found that the stimulatory effect of gonadotropins on invasion in ovarian cancer cells involve the PKA and PI3K pathways (Choi et al. 2006). Some studies suggested that the PKA via the IL-6/STAT3 pathway mediates gonadotropin-induced proliferation of OSE and ovarian cancer cells (Syed et al. 2001, 2002). Treatment of OEC cells with FSH significantly increased the levels of PKC $\alpha$ mRNA and protein, suggesting that the stimulation of $\mathrm{PKC} \alpha$ is involved in FSH-induced cell proliferation (Ohtani et al. 2001). Taken together, these observations suggest that gonadotropin-induced cAMP levels stimulate the activation of both PKA-dependent and -independent signaling pathways, resulting in diverse biological roles of gonadotropins in OSE and its neoplastic counterpart.

\section{Declaration of interest}

The authors declare that there is no conflict of interest that could be perceived as prejudicing the impartiality of the research reported. 


\section{Funding}

This work was supported by the Canadian Institutes of Health Research. PCKL is the recipient of a Distinguished Scholar Award from the Child and Family Research Institute. JHC and SLP were recipients of Studentship Awards from the Interdisciplinary Women's Reproductive Health Research Training Program. Dominant negative Epac mutant EpacR279E was generously provided by Dr X. Cheng (Department of Pharmacology and Toxicology, University of Texas Medical Branch).

\section{Acknowledgements}

We are thankful to Dr Auersperg (University of British Columbia, Vancouver, BC) and Dr Andrew Godwin (Fox Chase Cancer Center, Philadelphia, PA) for providing IOSE80PC cell lines.

\section{References}

Alam H, Maizels ET, Park Y, Ghaey S, Feiger ZJ, Chandel NS \& Hunzicker-Dunn M 2004 Follicle-stimulating hormone activation of hypoxia-inducible factor- 1 by the phosphatidylinositol 3-kinase/AKT/Ras homolog enriched in brain (Rheb)/mammalian target of rapamycin (mTOR) pathway is necessary for induction of select protein markers of follicular differentiation. Journal of Biological Chemistry 279 19431-19440.

Alper O, De Santis ML, Stromberg K, Hacker NF, ChoChung YS \& Salomon DS 2000 Anti-sense suppression of epidermal growth factor receptor expression alters cellular proliferation, cell-adhesion and tumorigenicity in ovarian cancer cells. International Journal of Cancer $\mathbf{8 8}$ 566-574.

Babu PS, Krishnamurthy H, Chedrese PJ \& Sairam MR 2000 Activation of extracellular-regulated kinase pathways in ovarian granulosa cells by the novel growth factor type 1 follicle-stimulating hormone receptor. Role in hormone signaling and cell proliferation. Journal of Biological Chemistry 275 27615-27626.

Berns EM, Klijn JG, Henzen-Logmans SC, Rodenburg CJ, van der Burg ME \& Foekens JA 1992 Receptors for hormones and growth factors and (onco)-gene amplification in human ovarian cancer. International Journal of Cancer 52 218-224.

Biskind MS \& Biskind GR 1944 Development of tumors in the rat ovary after transplantation into the spleen. Proceedings of the Society for Experimental Biology and Medicine 55 176-179.

Brader KR, Wolf JK, Chakrabarty S \& Price JE 1998 Epidermal growth factor receptor (EGFR) antisense transfection reduces the expression of EGFR and suppresses the malignant phenotype of a human ovarian cancer cell line. Oncology Reports 5 1269-1274.

Cameron MR, Foster JS, Bukovsky A \& Wimalasena J 1996 Activation of mitogen-activated protein kinases by gonadotropins and cyclic adenosine $5^{\prime}$-monophosphates in porcine granulosa cells. Biology of Reproduction $\mathbf{5 5}$ 111-119.

Chiang M, Strong JA \& Asem EK 1997 Luteinizing hormone activates chloride currents in hen ovarian granulosa cells. Comparative Biochemistry and Physiology. Part A, Physiology 116 361-368.

Chin EC \& Abayasekara DR 2004 Progesterone secretion by luteinizing human granulosa cells: a possible cAMPdependent but PKA-independent mechanism involved in its regulation. Journal of Endocrinology 183 51-60.

Choi KC, Kang SK, Tai CJ, Auersperg N \& Leung PC 2001 Estradiol up-regulates antiapoptotic Bcl-2 messenger ribonucleic acid and protein in tumorigenic ovarian surface epithelium cells. Endocrinology 142 2351-2360.

Choi KC, Kang SK, Tai CJ, Auersperg N \& Leung PC 2002 Follicle-stimulating hormone activates mitogen-activated protein kinase in preneoplastic and neoplastic ovarian surface epithelial cells. Journal of Clinical Endocrinology and Metabolism 87 2245-2253.

Choi JH, Choi KC, Auersperg N \& Leung PC 2005 Gonadotropins upregulate the epidermal growth factor receptor through activation of mitogen-activated protein kinases and phosphatidyl-inositol-3-kinase in human ovarian surface epithelial cells. Endocrine-Related Cancer 12 407-421.

Choi JH, Choi KC, Auersperg N \& Leung PC 2006 Gonadotropins activate proteolysis and increase invasion through protein kinase A and phosphatidylinositol 3-kinase pathways in human epithelial ovarian cancer cells. Cancer Research 66 3912-3920.

Cooke BA 1999 Signal transduction involving cyclic AMPdependent and cyclic AMP-independent mechanisms in the control of steroidogenesis. Molecular and Cellular Endocrinology 151 25-35.

Cramer DW \& Welch WR 1983 Determinants of ovarian cancer risk. II. Inferences regarding pathogenesis. Journal of the National Cancer Institute 71 717-721.

Cunningham MA, Zhu Q, Unterman TG \& Hammond JM 2003 Follicle-stimulating hormone promotes nuclear exclusion of the forkhead transcription factor FoxO1a via phosphatidylinositol 3-kinase in porcine granulosa cells. Endocrinology 144 5585-5594.

Das S, Maizels ET, DeManno D, St Clair E, Adam SA \& Hunzicker-Dunn M 1996 A stimulatory role of cyclic adenosine $3^{\prime}, 5^{\prime}$-monophosphate in follicle-stimulating hormone-activated mitogen-activated protein kinase signaling pathway in rat ovarian granulosa cells. Endocrinology 137 967-974.

Dewi DA, Abayasekara DR \& Wheeler-Jones CP 2002 Requirement for ERK1/2 activation in the regulation of progesterone production in human granulosa-lutein cells is stimulus specific. Endocrinology 143 877-888.

Flores JA, Veldhuis JD \& Leong DA 1990 Folliclestimulating hormone evokes an increase in intracellular free calcium ion concentrations in single ovarian (granulosa) cells. Endocrinology 127 3172-3179. 
Flores JA, Leong DA \& Veldhuis JD 1992 Is the calcium signal induced by follicle-stimulating hormone in swine granulosa cells mediated by adenosine cyclic $3^{\prime}, 5^{\prime}-$ monophosphate-dependent protein kinase? Endocrinology 130 1862-1866.

Flores JA, Aguirre C, Sharma OP \& Veldhuis JD 1998 Luteinizing hormone $(\mathrm{LH})$ stimulates both intracellular calcium ion $\left(\left[\mathrm{Ca}^{2+}\right]_{\mathrm{i}}\right)$ mobilization and transmembrane cation influx in single ovarian (granulosa) cells: recruitment as a cellular mechanism of $\mathrm{LH}-\left[\mathrm{Ca}^{2+}\right]_{\mathrm{i}}$ dose response. Endocrinology 139 3606-3612.

Gadducci A, Cosio S, Gargini A \& Genazzani AR 2004 Sexsteroid hormones, gonadotropin and ovarian carcinogenesis: a review of epidemiological and experimental data. Gynecological Endocrinology 19 216-228.

Gao L, Feng Y, Bowers R, Becker-Hapak M, Gardner J, Council L, Linette G, Zhao H \& Cornelius LA 2006 Ras-associated protein-1 regulates extracellular signalregulated kinase activation and migration in melanoma cells: two processes important to melanoma tumorigenesis and metastasis. Cancer Research 66 7880-7888.

Gilchrist RL, Ryu KS, Ji I \& Ji TH 1996 The luteinizing hormone/chorionic gonadotropin receptor has distinct transmembrane conductors for cAMP and inositol phosphate signals. Journal of Biological Chemistry 271 19283-19287.

Gonzalez-Robayna IJ, Falender AE, Ochsner S, Firestone GL \& Richards JS 2000 Follicle-stimulating hormone (FSH) stimulates phosphorylation and activation of protein kinase B (PKB/Akt) and serum and glucocorticoidlnduced kinase (Sgk): evidence for A kinase-independent signaling by FSH in granulosa cells. Molecular Endocrinology 14 1283-1300.

Greenlee RT, Murray T, Bolden S \& Wingo PA 2000 Cancer statistics, 2000. CA: A Cancer Journal for Clinicians 50 7-33.

Hanna L \& Adams M 2006 Prevention of ovarian cancer. Best Practice \& Research. Clinical Obstetrics \& Gynaecology 20 339-362.

Herrlich A, Kuhn B, Grosse R, Schmid A, Schultz G \& Gudermann T 1996 Involvement of Gs and Gi proteins in dual coupling of the luteinizing hormone receptor to adenylyl cyclase and phospholipase C. Journal of Biological Chemistry 271 16764-16772.

Hirsch B, Kudo M, Naro F, Conti M \& Hsueh AJ 1996 The C-terminal third of the human luteinizing hormone (LH) receptor is important for inositol phosphate release: analysis using chimeric human LH/follicle-stimulating hormone receptors. Molecular Endocrinology 10 1127-1137.

Holschneider CH \& Berek JS 2000 Ovarian cancer: epidemiology, biology, and prognostic factors. Seminars in Surgical Oncology 19 3-10.

Hsueh AJ, Adashi EY, Jones PB \& Welsh TH Jr 1984 Hormonal regulation of the differentiation of cultured ovarian granulosa cells. Endocrine Reviews 5 76-127.
Kawasaki H, Springett GM, Mochizuki N, Toki S, Nakaya M, Matsuda M, Housman DE \& Graybiel AM 1998 A family of cAMP-binding proteins that directly activate Rap1. Science 282 2275-2279.

Konishi I 2006 Gonadotropins and ovarian carcinogenesis: a new era of basic research and its clinical implications. International Journal of Gynecological Cancer 16 16-22.

Kuhn B \& Gudermann T 1999 The luteinizing hormone receptor activates phospholipase $\mathrm{C}$ via preferential coupling to Gi2. Biochemistry 38 12490-12498.

Lu JJ, Zheng Y, Kang X, Yuan JM, Lauchlan SC, Pike MC \& Zheng W 2000 Decreased luteinizing hormone receptor mRNA expression in human ovarian epithelial cancer. Gynecologic Oncology 79 158-168.

Lukanova A \& Kaaks R 2005 Endogenous hormones and ovarian cancer: epidemiology and current hypotheses. Cancer Epidemiology, Biomarkers and Prevention 14 98-107.

Minegishi T, Kameda T, Hirakawa T, Abe K, Tano M \& Ibuki Y 2000 Expression of gonadotropin and activin receptor messenger ribonucleic acid in human ovarian epithelial neoplasms. Clinical Cancer Research 6 2764-2770.

Misra UK, Kaczowka SJ \& Pizzo SV 2008 Interaction between TCL1 and Epac1 in the activation of Akt kinases in plasma membranes and nuclei of 8-CPT-2-O-MecAMP-stimulated macrophages. Cell Signalling 20 130-138.

Nicholson RI, Gee JM \& Harper ME 2001 EGFR and cancer prognosis. European Journal of Cancer 37 S9-S15.

Nicosia SV \& Johnson JH 1984 Surface morphology of ovarian mesothelium (surface epithelium) and of other pelvic and extrapelvic mesothelial sites in the rabbit. International Journal of Gynecological Pathology 3 249-260.

Ohtani K, Sakamoto H, Kikuchi A, Nakayama Y, Idei T, Igarashi N, Matukawa T \& Satoh K 2001 Folliclestimulating hormone promotes the growth of human epithelial ovarian cancer cells through the protein kinase C-mediated system. Cancer Letters 166 207-213.

Owens OJ \& Leake RE 1992 Growth factor content in normal and benign ovarian tumours. European Journal of Obstetrics, Gynecology, and Reproductive Biology 47 223-228.

Owens OJ, Stewart C, Brown I \& Leake RE 1991 Epidermal growth factor receptors (EGFR) in human ovarian cancer. British Journal of Cancer 64 907-910.

Parrott JA, Doraiswamy V, Kim G, Mosher R \& Skinner MK 2001 Expression and actions of both the follicle stimulating hormone receptor and the luteinizing hormone receptor in normal ovarian surface epithelium and ovarian cancer. Molecular and Cellular Endocrinology 172 213-222.

Peng C, Fan NC, Ligier M, Vaananen J \& Leung PC 1994 Expression and regulation of gonadotropin-releasing hormone $(\mathrm{GnRH})$ and $\mathrm{GnRH}$ receptor messenger ribonucleic acids in human granulosa-luteal cells. Endocrinology 135 1740-1746. 
Pennybacker M \& Herman B 1991 Follicle-stimulating hormone increases c-fos mRNA levels in rat granulosa cells via a protein kinase C-dependent mechanism. Molecular and Cellular Endocrinology 80 11-20.

Quirk JT \& Natarajan N 2005 Ovarian cancer incidence in the United States, 1992-1999. Gynecologic Oncology 97 519-523.

Rangarajan S, Enserink JM, Kuiperij HB, de Rooij J, Price LS, Schwede F \& Bos JL 2003 Cyclic AMP induces integrin-mediated cell adhesion through Epac and Rap1 upon stimulation of the beta 2-adrenergic receptor. Journal of Cell Biology 160 487-493.

Riman T, Persson I \& Nilsson S 1998 Hormonal aspects of epithelial ovarian cancer: review of epidemiological evidence. Clinical Endocrinology 49 695-707.

de Rooij J, Zwartkruis FJ, Verheijen MH, Cool RH, Nijman SM, Wittinghofer A \& Bos JL 1998 Epac is a Rap1 guanine-nucleotide-exchange factor directly activated by cyclic AMP. Nature 396 474-477.

Salomon DS, Brandt R, Ciardiello F \& Normanno N $1995 a$ Epidermal growth factor-related peptides and their receptors in human malignancies. Critical Reviews in Oncology/Hematology 19 183-232.

Salomon DS, Brandt R, Ciardiello F \& Normanno N $1995 b$ Epidermal growth factor-related peptides and their receptors in human malignancies*1. Critical Reviews in Oncology/Hematology 19 183-232.

Sekar N \& Veldhuis JD 2001 Concerted transcriptional activation of the low density lipoprotein receptor gene by insulin and luteinizing hormone in cultured porcine granulosa-luteal cells: possible convergence of protein kinase a, phosphatidylinositol 3-kinase, and mitogenactivated protein kinase signaling pathways. Endocrinology 142 2921-2928.

Syed V, Ulinski G, Mok SC, Yiu GK \& Ho SM 2001 Expression of gonadotropin receptor and growth responses to key reproductive hormones in normal and malignant human ovarian surface epithelial cells. Cancer Research 61 6768-6776.

Syed V, Ulinski G, Mok SC \& Ho SM 2002 Reproductive hormone-induced, STAT3-mediated interleukin 6 action in normal and malignant human ovarian surface epithelial cells. Journal of the National Cancer Institute 94 617-629.

Touyz RM, Jiang L \& Sairam MR 2000 Follicle-stimulating hormone mediated calcium signaling by the alternatively spliced growth factor type I receptor. Biology of Reproduction 62 1067-1074.

Veldhuis JD 1987 Mechanisms subserving hormone action in the ovary: role of calcium ions as assessed by steady state calcium exchange in cultured swine granulosa cells. Endocrinology 120 445-449.

Wang Z, Liu X \& Ascoli M 1997 Phosphorylation of the lutropin/choriogonadotropin receptor facilitates uncoupling of the receptor from adenylyl cyclase and endocytosis of the bound hormone. Molecular Endocrinology 11 183-192.

Zheng W, Lu JJ, Luo F, Zheng Y, Feng Y, Felix JC, Lauchlan SC \& Pike MC 2000 Ovarian epithelial tumor growth promotion by follicle-stimulating hormone and inhibition of the effect by luteinizing hormone. Gynecologic Oncology 76 80-88. 